\title{
SOME FUNDAMENTAL PROBLEMS OF TECTONICS AND GEODYNAMICS OF THE CENTRAL ASIAN FOLDED BELT
}

\author{
I. V. Gordienko \\ Geological Institute of SB RAS, Ulan-Ude, Russia
}

\begin{abstract}
This study addresses some fundamental problems of tectonics and geodynamics of the Central Asian folded belt, the largest tectonic structure in Eurasia. The article presents results of long-term researches conducted by scientists and geologists specialized in various disciplines which contribute to the knowledge of the origin and breakup of Rodinia and formation of the Paleo-Asian Ocean. It considers problems of development of the Central Asian folded belt that was formed in the area of the Paleo-Asian Ocean and describes its subduction magmatism and marginal-marine sedimentation, formation of island arcs, processes of exhumation of the oceanic crust and formation of high-pressure blueschist and eclogite-blueschist complexes. Outstanding fundamental issues of the geodynamic evolution of the Central Asian folded belt are noted.
\end{abstract}

Key words: tectonics, geodynamics, indicative complexes, Paleo-Asian Ocean, Central Asian folded belt, island arcs, backarc basins.

Recommended by K.Zh. Seminsky

Citation: Gordienko I.V. 2014. Some fundamental problems of tectonics and geodynamics of the Central Asian folded belt. Geodynamics \& Tectonophysics 5 (3), 585-593. doi:10.5800/GT-2014-5-3-0144.

\section{НЕКОТОРЫЕ ФУНДАМЕНТАЛЬНЫЕ ПРОБЛЕМЫ ТЕКТОНИКИ И ГЕОДИНАМИКИ ЦЕНТРАЛЬНО-АЗИАТСКОГО СКЛАДЧАТОГО ПОЯСА}

\author{
И. В. Гордиенко \\ Геологический институт СО РАН, Улан-Удэ, Россия
}

Аннотация: В работе затронуты некоторые фундаментальные проблемы тектоники и геодинамики ЦентральноАзиатского складчатого пояса - крупнейшей тектонической структуры Евразии. Показаны результаты многолетних исследований ученых-геологов различного профиля, их вклад в познание образования и распада суперконтинента Родиния, а также формирования Палеоазиатского океана. Рассмотрены проблемы развития Центрально-Азиатского складчатого пояса, сформированного на месте Палеоазиатского океана, его субдукционного магматизма и окраинноморского осадконакопления, формирования островных дуг, процессы эксгумации океанической коры и формирования высокобарических глаукофансланцевых и эклогит-глаукофансланцевых комплексов. Обсуждены некоторые нерешенные фундаментальные вопросы геодинамической эволюции Центрально-Азиатского складчатого пояса.

Ключевые слова: тектоника, геодинамика, индикаторные комплексы, Палеоазиатский океан, Центрально-Азиатский складчатый пояс, островные дуги, задуговые бассейны. 


\section{1. ВВЕДЕНИЕ}

Фундаментальные вопросы формирования Центрально-Азиатского складчатого пояса (ЦАСП) как крупной тектонической структуры Евроазиатского континента длительное время занимали и продолжают занимать умы ученых разных стран. Складчатый пояс, ранее именовавшийся Урало-Монгольским, охватывает огромное пространство между Сибирской, СевероКитайской (Сино-Корейской) и Таримской платформами.

Согласно представлениям [Zonenshain et al., 1990], Центрально-Азиатский складчатый пояс как единая структура был сформирован к концу палеозоя за счет последовательного сближения и конечного столкновения Сибирского континента с Северо-Китайским, Таримским, Таджикским, Каракумским и Казахстано-Северо-Тянь-Шаньским древними массивами. В настоящее время установлено, что ЦАСП образовался на месте Палеоазиатского океана, который сформировался в позднем рифее в процессе распада суперконтинента Родиния и просуществовал до конца нижнего палеозоя. В последующем он трансформировался в Монголо-Охотский океанический бассейн. Палеоазиатский океан отделил Восточную Европу от Сибири, а Сибирь - от Тарима и Синокореи. Он простирался до Баренцева моря, где смыкался с Япетусом, и Карского моря, где соединялся с Палеопацификой, до современных Охотского и Японского морей, где происходило его другое соединение с Палеопацификой [Gordienko, Kuz'min, 1999; Khain, 2001; Dobretsov, 2003; Yarmolyuk et al., 2006; Gordienko, 1987, 2006; Didenko et al., 2010; Kheraskova et al., 2010].

Большая роль в изучении этой глобальной структуры принадлежит Е.В. Склярову, его ученикам и коллегам. За последние тридцать лет работами этого коллектива охвачены практически все фундаментальные проблемы, связанные с формированием Сибирского кратона и ЦАСП: механизм образования и распада суперконтинента Родиния, зарождение и раскрытие Палеоазиатского океана (ПАО) и формирования на его месте ЦАСП. Особенно интенсивно эта работа проводилась и проводится в последнее десятилетие в рамках фундаментальной проблемы ОНЗ РАН и СО РАН «Геодинамическая эволюция литосферы ЦентральноАзиатского подвижного пояса» (от океана к континенту)», которая успешно реализуется благодаря ежегодным научным совещаниям в Институте земной коры СО РАН под руководством члена-корреспондента РАН Е.В. Склярова. Этой программой охвачены крупные проблемы: 1) ранние этапы становления и эволюции Центрально-Азиатского складчатого пояса (мезо- и неопротерозой); 2) магматизм, метаморфизм и деформации литосферы на стадии закрытия Палеоазиатского океана (палеозой - мезозой); 3) палеомагнетизм, геодинамика и пространственно-временные реконструкции Центрально-Азиатского пояса и его обрамления.
Несмотря на продолжительное и интенсивное изучение геологии ЦАСП в истории геологического развития этой структуры остается множество нерешенных вопросов. Эти вопросы касаются не только более качественного и корректного выделения основных этапов эволюции складчатого пояса, но и заполнения имеющихся пробелов в истории его геодинамического развития. Важную роль в решении этих задач играет изучение индикаторных геологических комплексов, в том числе петрологических комплексов-индикаторов тектонической эволюции, а именно магматических и метаморфических комплексов, что позволяет с большей долей надежности реконструировать разнообразные тектонические процессы, определяющие формирование структуры ЦАСП [Sklyarov, 1994].

Остановимся кратко на некоторых вышеназванных проблемах формирования ЦАСП.

\section{2. НЕКОТОРЫЕ ФУНДАМЕНТАЛЬНЫЕ ПРОБЛЕМЫ ТЕКТОНИКИ И ГЕОДИНАМИКИ, СВЯЗАННЫЕ С ФОРМИРОВАНИЕМ ЦЕНТРАЛЬНО-АЗИАТСКОГО СКЛАДЧАТОГО ПОЯСА}

Центрально-Азиатский складчатый пояс занимает значительную область складчатого обрамления юга Сибирской платформы. До недавнего времени эта территория, особенно ее монгольская часть, в геологическом отношении оставалась слабоизученной. Однако благодаря исследованиям российских и монгольских геологов, проведенным за последние 50 лет, это положение резко изменилось. В настоящее время наиболее изученной является северная часть Центрально-Азиатского складчатого пояса, непосредственно примыкающая к краевым структурам юга Сибирской платформы. Этот регион включает в себя горные сооружения Алтая, Восточного и Западного Саяна, Восточной Тувы, Прибайкалья, Забайкалья и сопредельных районов Монголии.

Данная территория всегда привлекала внимание исследователей, во-первых, как крупнейшая рудная провинция и, во-вторых, как интересный в геологическом отношении регион, на примере которого развивались тектонические концепции, имеющие большое значение для науки («древнее темя Азии», «байкалиды», «салаириды», «байкальские каледониды», «аркогенез», «тектономагматическая активизация», «дива-структуры», «рифтогенез» и др.). Эти фиксистские концепции разрабатывались преимущественно на геологических материалах юга Восточной Сибири. Обобщающие работы по всему складчатому обрамлению юга Сибирской платформы, включая Монголию, появились только в 60-х годах прошлого века. Здесь, прежде всего, следует назвать «Тектоническую карту Евразии», составленную большим коллективом геологов под руководством академика А.Л. Яншина [Yanshin, 1965; Peive et al., 1976]. Тектоническое или структурно-формаци- 
онное районирование территории складчатого обрамления юга Сибирской платформы было основано на традиционном историко-геологическом анализе длительно развивавшихся подвижных областей Центрально-Азиатского складчатого пояса, которые в результате сложных геологических процессов были последовательно причленены к Сибирской платформе. Тектоническое районирование с выделением складчатых систем широко применялось при составлении тектонических карт Монголии и Забайкалья [Amantov, 1975; Tectonics..., 1974; Mossakovsky, 1975; Tectonics of Northern Eurasia, 1980; и др.].

Другой этап исследований наступил в конце 70-х начале 80-х годов и был связан с признанием большинством геологов нашей страны новой глобальной парадигмы развития Земли - тектоники литосферных плит, основные положения которой были опубликованы еще в начале 60-х годов. Этому способствовало появление целого ряда фундаментальных работ, прежде всего на русском языке [The New Global Tectonics, 1974; Le Pichon u дp., 1977; Zonenshain et al., 1976, 1990; Dobretsov, 1980, 1981; Kovalev, 1985; Kuz'min, 1985; Sorokhtin, Ushakov, 1991; Zonenshain, Kuz'min, 1993; Khain, 1995, 2003; и др.], по которым учились многие поколения геологов. В настоящее время на основе тектоники литосферных плит составлено и издано большое количество международных и региональных тектонических и геодинамических карт.

Успехи в изучении геодинамических режимов различных областей Земли с использованием методов тектоники литосферных плит позволили по-новому подойти к тектоническому районированию территории. Так, при исследовании магматических пород различного состава в складчатых областях Земли было установлено, что геохимические особенности пород практически не зависят от возраста, а определяются главным образом типом геодинамической обстановки, в которой они формировались. Было выявлено, что для каждой обстановки устанавливается строго определенное геодинамическое строение, ансамбль тектонических структур, магматических и метаморфических комплексов и связанных с ними месторождений полезных ископаемых. Каждой геодинамической обстановке свойственна своя совершенно определенная структурно-магматическая зональность, обусловленная главным образом увеличением щелочности магматических пород от фронтальной к тыловой части активных континентальных окраин и островных вулканических дуг. Однако иногда такая зональность нарушается, что связывается с постепенным заглублением очагов магмогенерации над погружающейся субдукционной зоной, вследствие чего с увеличением давления уменьшается степень плавления субстрата и возрастает щелочность формирующихся расплавов [Gordienko, Kuz'min, 1999].

В пределах Монголо-Забайкальского региона были выделены и охарактеризованы террейны, представля- ющие собой фрагменты рифейских и палеозойских островных дуг, активных континентальных окраин, океанической коры (офиолитов, симаунтов и др.), турбидитовых бассейнов, континентального склона и его подножия, шельфов, а также фрагменты кратонных террейнов (микроконтинентов), сложенных докембрийскими кристаллическими породами. Результатом аккреции являлось последовательное наращивание Сибирского континента в направлении с севера на юг (в современных координатах). Аккреция сопровождалась крупными сдвиговыми перемещениями, обусловленными клинообразной формой южного выступа Сибирского кратона, а также повторными деформациями, гранитообразованием и высокотемпературным коллизионным метаморфизмом в пределах ранее аккретированных террейнов и смежной окраины кратона. На исследованной территории отчетливо выделяются позднерифейские (или байкальские), венд-раннепалеозойские (или каледонские), среднепалеозойские (или раннегерцинские), позднепалеозойские (или позднегерцинские) этапы формирования тектонических структур и магматических комплексов [Gordienko, 2006, 2008].

В настоящее время из наиболее важных фундаментальных проблем геодинамической эволюции Сибирского кратона и формирования ЦАСП следует назвать решение отдельных вопросов формирования и распада суперконтинента Родиния, образование которого В.Е. Хаин назвал «смутным временем» [Khain, 2001]. Этими вопросами занимались многие иностранные и отечественные ученые. Проведено несколько международных симпозиумов. Однако наиболее надежные данные были получены при изучении роев даек основного состава как индикаторов рифтогенных режимов, сопутствующих формированию фундамента Сибирского кратона и его сочленения с ЦАСП [Sklyarov et al., 2000; Gladkochub et al., 2000, 2007; Metelkin et al., 2005]. Однако до сих пор время раскрытия ПАО остается дискуссионным (по разным оценкам от 1100 до 750 млн лет). По данным [Dobretsov, Buslov, 2007], раскрытие ПАО произошло в период 970-850 млн лет в результате воздействия суперплюма на суперконтинент Родиния и фиксируется возрастом базитовых даек внутри блоков Родинии. В реконструкции [Kheraskova et al., 2010] в это время ПАО отсутствовал. Он появляется только в интервале 850-800 млн лет назад.

Среди комплексов-индикаторов геодинамической эволюции складчатых областей особая роль принадлежит высокобарическим глаукофансланцевым и эклогит-глаукофансланцевым комплексам, которые отражают последовательность и характер субдукционноаккреционных событий на конвергентных границах литосферных плит. Работы в этом плане были начаты Н.Л. Добрецовым [Dobretsov, 1974] и продолжены Е.В. Скляровым [Sklyarov, 1994, 2006; Volkova, Sklyarov, 2007; и дp.], который впервые подробно охарактеризовал высокобарические комплексы: Окинский в Во- 
сточном Саяне, Агинский в Забайкалье и Хугейгольский в Западном Прихубсугулье. Было отмечено, что большинство глаукофансланцевых поясов южного обрамления Сибирского кратона сформировалось во внутриокеанической преддуговой обстановке, т.е. при субдукции океанической плиты под островную дугу. Следует отметить, что в пределах ЦАСП почти всегда отмечается большой разрыв во времени между образованием субдукционно-аккреционных комплексов и окончательной коллизией островодужных террейнов или микроконтинентов с Сибирским кратоном.

Установлена правильная периодичность глаукофансланцевого метаморфизма в 30 млн лет в мезозое $(30,60,90,120,150,180,210$ млн лет) и 30-60 млн лет в палеозое (300, 330, 365, 400, 460, 520 млн лет), которая подкрепляется не только геологическими и геохронологическими данными по глаукофансланцевым поясам, но и по данным возраста офиолитов, которые попадали в основном в эти же возрастные интервалы между максимумами глаукофансланцевого метаморфизма. Было показано, что эпохи спрединга, фиксируемые офиолитами, сменялись коллизией, складчатостью и быстрым выведением чешуй глаукофановых сланцев к поверхности. С интенсивностью этих геологических процессов тесно связано формирование коллизионного гранитоидного магматизма, гранитогнейсовых куполов и регионального метаморфизма [Dobretsov et al., 2001].

Ввиду особой индикаторной роли глаукофансланцевых и эклогит- глаукофансланцевых комплексов ЦАСП, эти работы необходимо продолжить, особенно на территории Монголо-Забайкальского региона, где широко проявлены процессы субдукционного магматизма и эксгумации древних эклогитовых, офиолитовых и островодужных комплексов, в том числе эклогитовых чешуй в Северо-Муйском кратонном террейне [Shatsky et al., 1996].

Согласно новой глобальной концепции тектоники литосферных плит установлено, что складчатые (орогенные) пояса возникли на месте бывших океанических бассейнов или их окраин и являются продуктом преобразования океанической коры в континентальную. Было выявлено, что в этом процессе главенствующую роль играют эндогенные факторы глубинной геодинамики, прежде всего субдукционный магматизм, который проявлен приемущественно в островных вулканических дугах и активных континентальных окраинах. Зоны субдукции являются важнейшими структурными элементами окраин океанов. Это наиболее активные зоны Земли. Без зон субдукции невозможно длительное существование зон спрединга срединно-океанических хребтов в океанах [Bogatikov et al., 2010; Dobretsov, 2011]. Отсюда изучение фрагментов океанической и континентальной коры геологического прошлого, запечатленных в офиолитовых, островодужных и окраинно-морских комплексах древних складчатых областей, представляет одну из фундамен- тальных проблем современной геологии.

Данная проблема уже длительное время изучается в рамках второго блока программы ОНЗ РАН - СО РАН «Геодинамическая эволюция...». Она посвящена исследованию фрагментов океанических бассейнов и орогенных структур, отвечающих стадии зрелого развития и закрытия Палеоазиатского океана и его трансформации в Центрально-Азиатский складчатый пояс. Этой проблеме посвящено огромное количество статей, львиную долю которых составляют работы сибирских геологов, прежде всего сотрудников ИЗК СО РАН, ГИН СО РАН, ГЕОХИ СО РАН, ИГМ СО РАН И др. Объектами исследований являлись следующие комплексы-индикаторы геодинамических обстановок: дифференцированные серии, характерные для развитых островодужных систем и задуговых и преддуговых бассейнов, шельфовые отложения пассивных окраин как свидетельства раскрытия новых океанических бассейнов; офиолиты и островодужные комплексы - индикаторы тектонических режимов в пределах развитых океанических бассейнов; магматические и метаморфические комплексы, осадочные отложения форландовых бассейнов - индикаторы коллизионных событий, характерных для завершающих этапов эволюции бассейнов, базальты океанических плато и островов; комплексы - индикаторы аккреционно-коллизионных и постколлизионных событий (син- и постколлизионные базит-ультрабазитовые комплексы, сини постколлизионные гранитоидные комплексы, высокотемпературные метаморфические комплексы; магматизм «slab window», синплутонические минглингдайки как индикаторы корово-мантийного взаимодействия; комплексы метаморфических ядер).

Субдукционный магматизм характерен для деструктивных (конвергентных) обстановок Земли. К этим обстановкам относятся островные дуги, активные континентальные окраины и зоны коллизий (континентальная субдукция). Субдукционный магматизм представлен преимущественно низкотитанистыми, а также низко- и субщелочными магматическими образованиями, в том числе бонинитами. С позиций тектоники плит зоны субдукции отвечают погружающейся (субдуцируемой) в мантию пластине литосферы (слэбу) мощностью 80-100 км. При этом слэбы не являются монолитными пластинами, а представляют собой мощные зоны деформации и расслоения. На определенной глубине вещество слэбов обезвоживается и плавится с «впрыскиванием» расплава и летучих компонентов в надсубдукционный мантийный клин, что также вызывает его частичное плавление, внедрение магмы в верхние горизонты коры и островодужный вулканизм [Oncken et al., 2008; Crawford, 1989; Herzberg et al., 2010; Dobretsov, 2010; Bogatikov et al., 2010].

Установлена секториальность зоны субдукции в верхней части субдуцирующей океанической плиты, надсубдукционной мантии и литосферы, где выделяет- 
ся пять секторов и три типа вулканизма, которые изменяются от толеит-бонинитовых до щелочно-базальтовых серий. Положение границ секторов и вулканических зон зависит от температурного режима субдуцирующей плиты и надсубдукционного мантийного клина [Dobretsov, 2010]. Островодужные вулканические и синхронные им плутонические породы обнаруживают много черт сходства, свидетельствующих об их комагматичности. Среди плутонитов преобладают гранодиориты, тоналиты, диориты, плагиограниты. По сравнению с вулканитами эти породы несколько богаче $\mathrm{SiO}_{2}$ и некогерентными элементами, существенное перекрытие отличается и в отношении ${ }^{87} \mathrm{Sr} /{ }^{86} \mathrm{Sr}$, хотя региональные вариации стронция однотипны.

Задуговые окраинные осадочные бассейны также являются составным элементом деструктивных островодужных обстановок. Это области задугового спрединга, где, как и в срединно-океанических хребтах, может происходить новообразование океанической коры. Среди них выделяются три типа бассейнов: 1) задуговые моря, развитые преимущественно вдоль западной периферии Тихого океана; 2) задуговые седиментационные бассейны на активных континентальных окраинах; 3) задуговые бассейны в зоне коллизии континентальных плит (например, в Альпийском поясе), где они развиты в форме задуговых морей и континентальных седиментационных бассейнов.

Земная кора задуговых морей обычно имеет сложное строение. В большинстве случаев здесь наблюдаются фрагменты утоненной (20-30 км) коры континентального типа (так называемая «промежуточная кора») и участки новообразованной коры океанического типа. Масштабы развития последней варьируются в широких пределах. Характер магматизма задуговых морей в целом аналогичен наблюдаемому в океанах [Bogdanov, 1988]. В пределах глубоководных участков ложа развиты преимущественно MORB, на которые «насажены» вулканические острова и подводные горы, образованные высокотитанистыми толеитами и субщелочными оливиновыми базальтами, типичными для внутриплитного магматизма.

Задуговые бассейны имеют тенденцию к одностороннему «растеканию» с продвижением со временем дуги в сторону океана или континента. Такое «растекание» может происходить повсеместно, как это наблюдается в случае Тирренского моря или Паннонской впадины, а может - скачками, как в Филиппинском море [Bogdanov, 1988]. При этом в тылу задуговых морей, уже на континенте, часто возникают синхронные по времени системы окраинно-континентальных рифтов, широко развитые, например, вдоль Западной Пацифики [Fedorov, 2006]. Очевидно, это может свидетельствовать о том, что в процессы растяжения при растекании головной части плюма в сторону океана вовлекаются и краевые части материка. Таким образом, задуговые бассейны являются мощными центрами эндогенной активности, которые в значительной мере определяют характер процессов на конвергентных границах плит.

Для исследования субдукционного магматизма в пределах Монголо-Забайкальского региона значительный интерес представляют Центрально-Азиатский и Монголо-Охотский орогенные пояса, возникшие на месте Палеоазиатского и Монголо-Охотского океанов [Zonenshain et al., 1976]. За время существования этих океанов в их пределах формировались и исчезали тектонические структуры различной геодинамической природы: энсиматические и энсиалические островные дуги, внутриокеанические вулканические острова (симаунты, гайоты) и рифтовые долины с различной скоростью спрединга, окраинные и внутренние моря, пассивные и активные континентальные окраины западно-тихоокеанского, калифорнийского и андийского типа. Формирование этих структур сопровождалось и во многом было обусловлено образованием разнообразных магматических и осадочных комплексов в различных частях названных орогенных поясов [Gordienko, 2006, 2008].

Известно, что территория Забайкалья и Монголии является уникальным регионом развития магматических пород, прежде всего разнообразных вулканогенных пород, ультрабазитов, габброидов и гранитоидов, которые проявились в различных геодинамических обстановках. В венде и раннем кембрии образовались мантийные базальт-бонинитовые серии, ультрабазиты, габброиды и гранитоиды толеитового и андезитового ряда, связанные с формированием надсубдукционных комплексов примитивных энсиматических островных дуг (Шишхидгольская, Джидинская и Келянская островодужные системы). В их образовании основную роль играли продукты плавления субдукционных слэбов верхней мантии. Вторую, наиболее распространенную, группу составляют смешанные корово-мантийные дифференцированные вулканические серии, габброиды и гранитоиды, характерные для энсиалических островных дуг (Удино-Витимская, Метешихинская и Ангино-Таланчанская островодужные системы). Необходимо отметить, что геохронологические и изотопные исследования палеозойских гранитоидов юга Сибири и Монголии свидетельствуют о том, что большая их часть характеризуется низкими первичными отношениями $\mathrm{Sr}$, положительными величинами छNd(T) и молодыми Nd модельными возрастами $\mathrm{TNd}(\mathrm{DM})=0.9-0.3$ млрд лет [Kovalenko et al., 1999]. Это коренным образом отличает рассматриваемую планетарную структуру ЦАСП от классических орогенных поясов каледонид-герцинид. Разработанные к настоящему времени модели о природе ювенильной континентальной коры предполагают, что она возникла в результате аккреции островных дуг и последующей ее тектоно-термальной переработки. В соответствии с этим считается, что обширные поля гранитоидов образовались вследствие структурного и вещественного преобразования этой ювенильной коры 
[Şengör et al., 1993; Kovalenko et al., 1999; Zorin et al., 2009].

Предполагается, что ювенильная континентальная кора каледонид была образована в результате частичного плавления в зонах субдукции океанических базитов и древних осадочных пород [Bogatikov et al., 2010]. Широко развитые субдукционные вулканоплутонические ассоциации островных дуг по изотопным характеристикам представляют собой ювенильную, переходную от океанической к континентальной, кору. Офиолиты рассматриваются в качестве возможного источника такой коры. И те, и другие магматиты Забайкалья и Монголии остаются еще слабоизученными как в изотопном, так и в геохимическом отношении, что не позволяет разработать достаточно полные геодинамические модели их формирования и эволюции континентальной коры. Остаются нерешенными ряд других фундаментальных проблем по эволюции субдукционного магматизма и условий формирования основных типов структур Центрально-Азиатского и Монголо-Охотского складчатых поясов.

\section{3. ЗАКЛЮЧЕНИЕ}

Центрально-Азиатский складчатый пояс, ранее именовавшийся Урало-Монгольским, охватывает огромное пространство между Сибирской, Северо-Китайской (Сино-Корейской) и Таримской платформами. Пояс образовался на месте Палеоазиатского океана, возникшего в позднем рифее в процессе распада суперконтинента Родиния, и просуществовал до конца нижнего палеозоя. В дальнейшем (в верхнем палеозое и мезозое) он трансформировался в Монголо-Охотский океанический бассейн. Известно, что уже на ранней стадии развития Палеоазиатского океана (в позднем рифее и начале венда) по западной окраине Восточной Гондваны образовалась непрерывная цепь островодужных систем (Кадомская, Протоуральская и другие), где выделяются островодужные вулканические серии с бонинитами, указывающими на максимальное раскрытие этого океана. По данным [Dobretsov, 2003], активное развитие океана и формирование ЦАСП происходили во вторую стадию (630-540 млн лет), то есть в венде-кембрии. В это время образовались спрединговые зоны СОХ, энсиматические (примитивные) и энсиалические (зрелые) островные дуги с протяженными зонами субдукции, преддуговые, задуговые бассейны и междуговые спрединговые окраинные моря. Главным в истории ЦАСП считается рубеж 570 млн лет [Yarmolyuk et al., 2006]. Именно к этому рубежу приурочено формирование большинства офиолитовых комплексов по сибирской окраине Палеоазиатского океана.

Среди нерешенных фундаментальных проблем тектоники и геодинамики ЦАСП необходимо отметить следующие.

1. Факт существования ПАО и ЦАСП, выделенных Л.П. Зоненшайном в 70-х годах прошлого столетия, не вызывает сомнения и признается всеми исследователями. Однако до сих пор неясно, когда и в каких размерах образовался ПАО и как в дальнейшем на его месте возник ЦАСП, в результате распада каких континентов или только Родинии. Существуют различные данные о конфигурации, времени образования и распада суперконтинента Родиния. Например, по мнению Т.Н. Херасковой [Kheraskova et al., 2010], Сибирский континент в это время вообще не входил в состав Родинии.

2. В настоящее время недостаточно палеомагнитных данных для реконструкции островодужных систем по окраинам ПАО. Это не позволяет показать достоверную полярность островных дуг и направлений падения зон субдукции. В реконструкциях островных дуг ПАО пока существует два подхода: 1) во всех выделенных разновозрастных островных дугах зоны субдукции падают под Сибирский континент [Zorin et al, 2009; Donskaya et al., 2012; Metelkin, 2012; и дp.] и 2) островные дуги имеют разную полярность и зоны субдукции падают как под Сибирский континент, так и под микроконтиненты [Gordienko 2006, 2008; Kheraskova et al., 2010; Dobretsov, 2011].

3. Плохо изучены зоны коллизии литосферных плит, их размерность, деформируемость, раздробленность, что влияет на масштабы и формы проявления аккреционно-коллизионного магматизма.

4. Во многом неясен механизм формирования задуговых осадочных бассейнов. По мнению [Dobretsov, 2011], в условиях максимального прогрева в зонах растяжения (рифтогенеза) вместо осадочных прогибов могут проявиться гранитогнейсовые купола и гранитные интрузии.

5. Недостаточно разработаны вопросы о роли плюмов в образовании разнообразного магматизма в зонах субдукции. Непонятно, как появились островодужные системы при прохождении океанических и континентальных плит над горячими точками мантии.

Все вышеперечисленные проблемы имеют прямое отношение к развитию структур ЦАСП, где широко развит субдукционный и внутриплитный магматизм, а также окраинно-морское осадконакопление.

\section{4. ЛИTEPATУPA / REFERENCES}

Amantov V.A., 1975. Tectonics and Rock Series of Transbaikalia and Northern Mongolia. Nedra, Leningrad, 224 p. (in Russian) [Амантов В.А. Тектоника и формации Забайкалья и Северной Монголии. Л.: Недра, 1975. 224 с.].

Bogatikov O.A., Kovalenko V.I., Sharkov E.V., 2010. Magmatism, Tectonics, Geodynamics of Earth. Time and Space Rela- 
tionship. Nauka, Moscow, 606 p. (in Russian) [Богатиков О.А., Коваленко В.И., Шарков Е.В. Магматизм, тектоника, геодинамика Земли. Связь во времени и пространстве. М.: Наука, 2010. 606 с.].

Bogdanov N.A., 1988. Tectonics of Deep-Sea Basins of Marginal Seas. Nedra, Moscow, 221 p. (in Russian) [Богданов Н.А. Тектоника глубоководных впадин окраинных морей. М.: Недра, 1988. 221 с.].

Crawford A.J. (Ed.), 1989. Boninites. Unwin Hyman, London, 345 p.

Didenko A.N., Malyshev Yu.F., Saksin B.G. (Eds.), 2010. The Deep Structure and Metallogeny of East Asia. Dal'nauka, Vladivostok, 332 p. (in Russian) [Глубинное строение и металлогения Восточной Азии / Под ред. А.Н. Диденко, Ю.Ф. Малышева, Б.Г. Саксина. Владивосток: Дальнаука, 2010. 332 с.].

Dobretsov N.L., 1974. Blueschist and Eclogite-Blueschist Complexes of the USSR. Nauka, Novosibirsk, 430 p. (in Russian) [Добрецов Н.Л. Глаукофансланцевые и эклогит-глаукофансланцевые комплексы СССР. Новосибирск: Наука, 1974. 430 c.].

Dobretsov N.L., 1980. Introduction to Global Petrology. Nauka, Novosibirsk, 200 p. (in Russian) [Добрецов Н.Л. Введение в глобальную петрологию. Новосибирск: Наука, 1980. 200 с.].

Dobretsov N.L., 1981. Global Petrological Processes. Nedra, Moscow, 236 p. (in Russian) [Добрецов Н.Л. Глобальные петрологические процессы. М.: Недра, 1981. 236 с.].

Dobretsov N.L., 2003. Evolution of structures of the Urals, Kazakhstan, Tien Shan, and Altai-Sayan region within the UralMongolian fold belt (Paleoasian ocean). Geologiya i Geofizika (Russian Geology and Geophysics) 44 (1-2), 5-27.

Dobretsov N.L., 2010. Distinctive petrological, geochemical, and geodynamic features of subduction-related magmatism. Petrology 18 (1), 84-106. http://dx.doi.org/10.1134/S0869591110010042.

Dobretsov N.L., 2011. Fundamentals of Tectonics and Geodynamics. Novosibirsk State University, Novosibirsk, 492 p. (in Russian) [Добрецов Н.Л. Основы тектоники и геодинамики. Новосибирск: НГУ, 2011. 492 с.].

Dobretsov N.L., Buslov M.M., 2007. Late Cambrian-Ordovician tectonics and geodynamics of Central Asia. Russian Geology and Geophysics 48 (1), 71-82. http://dx.doi.org/10.1016/j.rgg.2006.12.006.

Dobretsov N.L., Kirdyashkin A.G., Kirdyashkin A.A., 2001. Deep Geodynamics, 2nd ed., ext. and rev. Publishing House of SB RAS, Novosibirsk, 2001. 409 р. (in Russian) [Добрецов Н.Л., Кирдяшкин А.Г., Кирдяшкин А.А. Глубинная геодинамика. 2-е изд., доп. и перераб. Новосибирск: Изд-во СО РАН. 2001. 409 с.].

Donskaya T.V., Gladkochub D.P., Mazukabzov A.M., De Waele B., Presnyakov S.L., 2012. The Late Triassic Kataev volcanoplutonic association in western Transbaikalia, a fragment of the active continental margin of the Mongol-Okhotsk Ocean. Russian Geology and Geophysics 53 (1), 22-36. http://dx.doi.org/10.1016/j.rgg.2011.12.002.

Fedorov P.I., 2006. Cenozoic volcanism in tension zones at the eastern margin of Asia. GEOS, Moscow, 316 p. (in Russian) [Федоров П.И. Кайнозойский вулканизм в зонах растяжения на восточной окраине Азии. М.: ГЕОС, 2006. 316 с.].

Gladkochub D.P., Donskaya T.V., Mazukabzov A.M., Stanevich A.M., Sklyarov E.V., Ponomarchuk V.A., 2007. Signature of precambrian extension events in the southern Siberian craton. Russian Geology and Geophysics 48 (1), 17-31. http://dx.doi.org/10.1016/j.rgg.2006.12.001.

Gladkochub D.P., Sklyarov E.V., Mazukabzov A.M., Men'shagin Yu.V., Ponomarchuk V.A., 2000. Neoproterozoic Dike Swarms in the Sharyzhalgai Salient: Indicators of the Paleoasian Ocean Opening. Doklady Earth Sciences 375A (9), 1354-1358.

Gordienko I.V., 1987. Paleozoic Magmatism and Geodynamics of the Central Asian Folded Belt. Nauka, Moscow, 240 p. (in Russian) [Гордиенко И.В. Палеозойский магматизм и геодинамика Центрально-Азиатского складчатого пояса. М.: Наука, 1987. 240 с.].

Gordienko I.V., 2006. Geodynamic evolution of late Baikalides and Paleozoids in the folded periphery of the Siberian craton. Russian Geology and Geophysics (Geologiya i Geofizika) 47 (1), 51-67.

Gordienko I.V., 2008. The Earth Evolution History. Textbook. Geo, Novosibirsk, 293 p. (in Russian) [Гордиенко И.В. История развития Земли: Учеб. пособие. Новосибирск: Гео, 2008. 293 с.].

Gordienko I.V., Kuz'min M.I., 1999. Geodynamics and metallogeny of the Mongolo-Transbaikalian region. Geologiya i Geofizika (Russian Geology and Geophysics) 40 (11), 1545-1562.

Herzberg C., Condie K., Korenaga J., 2010. Thermal history of the Earth and its petrological expression. Earth and Planetary Science Letters 292 (1-2), 79-88. http://dx.doi.org/10.1016/j.epsl.2010.01.022.

Khain V.E., 1995. Main Problems of Modern Geology. Nauka, Moscow, 190 p. (in Russian) [Хаин В.Е. Основные проблемы современной геологии. М.: Наука, 1995. 190 с.].

Khain V.E., 2001. Tectonics of Continents and Oceans. Nauchny Mir, Moscow, 606 p. (in Russian) [Хаин B.E. Тектоника континентов и океанов. М.: Научный мир, 2001. 606 с.].

Khain V.E., 2003. Main Problems of Modern Geology. Nauchny Mir, Moscow, 348 p. (in Russian) [Хаин B.E. Основные проблемы современной геологии. М.: Научный мир, 2003. 348 с.].

Kheraskova T.N., Bush V.A., Didenko A.N., Samygin S.G., 2010. Breakup of Rodinia and early stages of evolution of the Paleoasian ocean. Geotectonics 44 (1), 3-24. http://dx.doi.org/10.1134/S0016852110010024. 
Kovalenko V.I., Yarmolyuk V.V., Kovach V.P., Budnikov S.V., Zhuravlev D.Z., Kozakov I.K., Kotov A.B., Rytsk E.Yu., Sal'Nikova E.B., 1999. Magmatism as Factor of Crust Evolution in the Central Asian Foldbelt: Sm-Nd Isotopic Data. Geotectonics 33 (3), 191-208.

Kovalev A.A., 1985. Mobilism and Geological Prospecting Criteria. Nedra, Moscow, 224 p. (in Russian) [Ковалев A.A. Mобилизм и поисковые геологические критерии. М.: Недра, 1985. 224 с.].

Kuz'min M.I., 1985. Geochemistry of Magmatic Rocks of Phanerozoic Mobile Belts. Nauka, Novosibirsk, 199 p. (in Russian) [Кузьмин М.И. Геохимия магматических пород фанерозойских подвижных поясов. Новосибирск: Наука, 1985. 199 c.].

Le Pichon, K., Franshto J., Bonnin J., 1977. Plate Tectonics. Mir, Moscow, 288 p. (in Russian) [Ле Пишон К., Франшто Ж., Боннин Ж. Тектоника плит. М.: Мир, 1977. 288 с.].

Metelkin D.V., 2012. The Evolution of Structures in Central Asia and the Role of Shear Tectonics According to Paleomagnetic Data. INGG, SB RAS, Novosibirsk, 458 p. (in Russian) [Метелкин Д.В. Эволюция структур Центральной Азии и роль сдвиговой тектоники по палеомагнитным данным. Новосибирск: ИНГГ СО РАН, 2012. 458 с.].

Metelkin D.V., Vernikovsky V.A., Kazanskii A.Yu., Belonosov I.V., 2005. The Siberian Craton in the structure of the supercontinent Rodinia: analysis of paleomagnetic data. Doklady Earth Sciences 404 (7), 1021-1026.

Mossakovsky A.A., 1975. Orogenic Structures and Volcanism of Paleozoids of Eurasia. Nauka, Moscow, 318 p. (in Russian) [Моссаковский А.А. Орогенные структуры и вулканизм палеозоид Евразии. М.: Наука, 1975.318 с.].

Oncken O., Chong G., Franz G., Giese P., Götze H.-J., Ramos V.A., Strecker M.R., Wigger P. (Eds.), 2008. Andes: Active Subduction Orogeny. Springer, Dordrecht, 610 p.

Peive A.V., Yanshin A.L., Zonenshain L.P. et al., 1976. Formation of continental crust in North Eurasia: in view of a new tectonic map. Geotektonika (Geotectonics) (5), 6-23 (in Russian) [ Пейве А.В., Яншин А.Л., Зоненшайн Л.П. и др. Становление континентальной земной коры Северной Евразии (в связи с составлением новой тектонической карты) // Геотектоника. 1976. № 5. С. 6-23].

Şengör A.M.C., Natal'in B.A., Burtman V.S. 1993. Evolution of the Altaid tectonic collage and Paleozoic crustal growth in Eurasia. Nature 364 (6435), 299-307. http://dx.doi.org/10.1038/364299a0.

Shatsky V.S., Yagoutz E., Ryboshlykov Yu.V., Koz'menko O.A., Vavilov M.A., 1996. Eclogites of the Northern Muya block: evidence of the Vendian collision in the Baikal-Muya ophiolite complex. Doklady AN 350 (5), $677-680$ (in Russian) [Шацкий В.С., Ягоути Э., Рыбошлыков Ю.В., Козьменко О.А., Вавилов М.А. Эклогиты Северо-Муйской глыбы: свидетельство венской коллизии в Байкало-Муйском офиолитовом комплексе // Доклады АН. 1996. Т. 350 . № 5. С. 677-680].

Sklyarov E.V., 1994. Petrological Indicators of the Tectonic Evolution of the Central Asian Folded Belt (North-Eastern Fragment). Synopsis of the thesis for Doctor of Geology and Mineralogy degree. IEC SB RAS, Irkutsk, 52 p. (in Russian) [Скляров E.B. Петрологические индикаторы тектонической эволюции Центрально-Азиатского складчатого пояса (северо-восточный фрагмент): Автореф. дис. ... докт. геол.-мин. наук. Иркутск: ИЗК СО РАН, 1994. 52 c.].

Sklyarov E.V., 2006. Exhumation of metamorphic complexes: basic mechanisms. Russian Geology and Geophysics (Geologiya i Geofizika) 47 (1), 68-72.

Sklyarov E.V., Gladkochub D.P., Mazukabzov A.M., Men'shagin Y.V., Konstantinov K.M., Watanabe T., 2000. Dike swarms on the southern flank of the Siberian Craton as indicators of the Rodinia supercontinent breakup. Geotectonics 34 (6), 482-496.

Sorokhtin O.G., Ushakov S.A., 1991. The Global Evolution of Earth. Moscow State University, Moscow, 446 p. (in Russian) [Сорохтин О.Г., Ушаков С.А. Глобальная эволюция Земли. М.: МГУ, 1991. 446 с.].

Tectonics of Northern Eurasia: an explanatory note to the Tectonic Map of Northern Eurasia, scale 1: 5000000. Nauka, Moscow, 219 p. (in Russian) [Тектоника северной Евразии: объяснительная записка к Тектонической карте северной Евразии масштаба 1:5000000. М.: Наука, 1980. 219 с.]

Tectonics of the Mongolian People's Republic, 1974. Nauka, Moscow, 284 р. (in Russian) [Тектоника Монгольской Народной Республики. М.: Наука, 1974. 284 с.].

The New Global Tectonics: Plate Tectonics, 1974. Translation from English. - Mir, Moscow, 472 p. (in Russian) [Hoвaя глобальная тектоника: (тектоника плит). Пер. с англ. М.: Мир, 1974. 472 с.].

Volkova N.I., Sklyarov E.V., 2007. High-pressure complexes of Central Asian fold belt: geologic setting, geochemistry, and geodynamic implicate. Russian Geology and Geophysics 48 (1), 83-90. http://dx.doi.org/10.1016/j.rgg.2006.12.008.

Yanshin A.P., 1965. Tectonic structure of Eurasia. Geotektonika (Geotectonics) (5), 7-34 (in Russian) [Яншин А.П. Тектоническое строение Евразии // Геотектоника. 1965. № 5. С. 7-34].

Yarmolyuk V.V., Kovalenko V.I., Kovach V.P., Rytsk E.Y., Kozakov I.K., Kotov A.B., Sal'nikova E.B., 2006. Early stages of the Paleoasian Ocean formation: Results of geochronological, isotopic, and geochemical investigations of Late Riphean and Vendian-Cambrian complexes in the Central Asian Foldbelt. Doklady Earth Sciences 411 (1), 1184-1189. http://dx.doi.org/10.1134/S1028334X06080046.

Zonenshain L.P., Kuz'min M.I., 1993. Paleogeodynamics. Nauka, Moscow, 192 p. (in Russian) [Зоненшайн Л.Л., Кузьмин М.И. Палеогеодинамика. М.: Наука, 1993. 192 с.]. 
Zonenshain L.P., Kuz'min M.I., Moralev V.M., 1976. Global Tectonics, Magmatism and Metallogeny. Nedra, Moscow, 232 p. (in Russian) [Зоненшайн Л.П., Кузьмин М.И., Моралев В.М. Глобальная тектоника, магматизм и металлогения. М.: Недра, 1976. 232 c].

Zonenshain L.P., Kuz'min M.I., Natapov L.M., 1990. Plate Tectonics of the USSR Territory. Nedra, Moscow, V. 1, 326 p.; V. 2, 328 р. (in Russian) [Зоненшайн Л.П., Кузьмин М.И., Натапов Л.М. Тектоника литосферных плит территории СССР. М.: Недра, 1990. Т. 1. 326 с.; Т. 2. 328 с.].

Zorin Yu.A., Sklyarov E.V., Belichenko V.G., Mazukabzov A.M., 2009. Island arc-back-arc basin evolution: implications for Late Riphean - Early Paleozoic geodynamic history of the Sayan-Baikal folded area. Russian Geology and Geophysics 50 (3), 149-161. http://dx.doi.org/10.1016/j.rgg.2008.06.022.

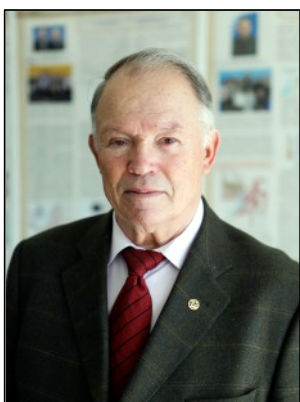

Гордиенко Иван Власович, чл.-корр. РАН, докт. геол.-мин. наук, советник РАН, г.н.с. Геологический институт СО РАН

670047, Улан-Удэ, ул. Сахьяновой, 6а, Россия

Тел.: 8(3012)433891; $₫$ e-mail: gord@pres.bscnet.ru

Gordienko, Ivan V., Corresponding Member of the RAS, Counsellor of the RAS, Chief Researcher Geological Institute of SB RAS

6a Sakhianovoy street, Ulan-Ude 670047, Russia

Tel.: 8(3012) 433891; \ e-mail: gord@pres.bscnet.ru 